\title{
Maintaining the Restriction on Neonicotinoids in the European Union - Benefits and Risks to Bees and Pollination Services
}

\author{
Björn K. Klatt ${ }^{1 *}$, Maj Rundlöf ${ }^{2}$ and Henrik G. Smith ${ }^{1,2}$ \\ ${ }^{1}$ Centre for Environmental and Climate Research, Lund University, Lund, Sweden, ${ }^{2}$ Department of Biology, Lund University, \\ Lund, Sweden
}

Keywords: environmental risks, European policy, insecticides, non-target organisms, pest control, risk assessment

\section{OPEN ACCESS}

Edited by:

Maria Tsiafouli,

Aristotle University of Thessaloniki,

Greece

Reviewed by:

Panagiotis N. Moschou,

Swedish University of Agricultural

Sciences, Sweden

Nigel E. Raine,

University of Guelph, Canada

*Correspondence:

Björn K. Klatt

klattbk@googlemail.com

Specialty section:

This article was submitted to Agroecology and Land Use Systems,

a section of the journal

Frontiers in Ecology and Evolution

Received: 19 July 2015

Accepted: 14 January 2016

Published: 03 February 2016

Citation:

Klatt BK, Rundlöf $M$ and Smith HG (2016) Maintaining the Restriction on Neonicotinoids in the European

Union - Benefits and Risks to Bees and Pollination Services.

Front. Ecol. Evol. 4:4.

doi: 10.3389/fevo.2016.00004
Globally, most crops are entomophilous (Klein et al., 2007), and thus yield is dependent on or at least benefits from pollination services. Wild bees are, together with honey bees, important providers of these crop pollination services (Garibaldi et al., 2013). Recent findings suggest, that bee pollination not only improves yield, but also the quality of agricultural products-including several aspects such as appearance, nutrient content, or shelf life (Klatt et al., 2014). Both, the amount and importance of entomophilous crops, are increasing (Lautenbach et al., 2012; Smith et al., 2015), thereby contributing to feeding an increasing world population (Godfray et al., 2010). However, bees in agricultural landscapes are exposed to several pressures. The use of pesticides, which is an integral part of contemporary agriculture, has among other factors been proposed to contribute to bee declines (Goulson et al., 2015), supposedly endangering pollination services (Chagnon et al., 2015; Stanley et al., 2015).

Since the early 90s, neonicotinoids have provided a powerful and increasingly used tool against insect pests in many crops, including those visited by bees and other pollinators (Elbert et al., 2008). Concerns about negative effects of neonicotinoids on bees recently resulted in a European Union-wide restriction on the use of three neonicotinoids (clothianidin, imidacloprid, and thiamethoxam) as seed treatment in bee-attractive crops to allow time to clarify their potential environmental impacts (European Commission, 2013). Such a restriction beyond the re-assessment in 2015 (European Commission, 2013) will cause significant changes in pest control management (Hughes et al., 2014). While the debate in science, policy, and the public has focused on effects of neonicotinoid on bees, we argue that it is essential to also evaluate the consequences of alternative pest control strategies (Gray and Hammitt, 2000).

The extent to which neonicotinoids benefit yields is not clear (Goulson, 2013; Noleppa and Hahn, 2013; United States Environmental Protection Agency, 2014). However, as the active substance is systemic and thus becomes distributed to all tissues, neonicotinoids can particularly target herbivorous pest insects in treated crops (Elbert et al., 2008). Thus, unless consumers accept higher food prices, restrictions on the use of neonicotinoids will require farmers to find suitable alternatives.

Continued restriction of the neonicotinoids will most likely result in an increased use of other classes of insecticides. Organophosphates, carbamates, and pyrethroids dominated the insecticide market before the approval of imidacloprid in the early 1990s initiated the global dominance of neonicotinoids as seed treatments (Elbert et al., 2008). Although many organophosphates and carbamates are no longer approved for use following recent re-evaluations by the European Commission (European Commission - Pesticides Database, 2015), approved active ingredients from these two large insecticide classes 
could nevertheless provide suitable alternatives to the restricted neonicotinoids: most organophosphates and many carbamates are also systemic (Sánchez-Bayo et al., 2013) and thus can potentially target a similar range of pests (Elbert et al., 2008). However, active substances from both classes suffer from pest resistance (Arthropod Pesticide Resistance Database, 2015). Pyrethroids are not systemic (Essential Chemical Industry online, 2015) and problems with pest resistance have been found (Heimbach and Müller, 2013; Arthropod Pesticide Resistance Database, 2015). Newer classes of insecticides such as, pyridinazomethines (e.g., pymetrozine), phenylpyrazoles (e.g., fipronil) or the non-systemic, but plant-tissue infiltrating oxadiacines (e.g., indoxacarb) (European Commission - Pesticides Database, 2015) may be other potential alternatives. In addition, not all neonicotinoids are restricted (European Commission, 2013; European Commission - Pesticides Database, 2015). In particular acetamiprid and thiacloprid may be preferred alternatives in crops that are attractive to bees, as they also function systemically and are considered to be less acutely toxic to bees than their restricted and unrestricted (nitenpyram, dinotefuran) relatives (Blacquière et al., 2012; European Commission, 2013).

Active substances from many insecticide classes that may replace the restricted neonicotinoids have already been shown to cause mortality in adults and larvae of honey bees, bumble bees and solitary bees (European Food Safety Authority, 2012; Arena and Sgolastra, 2014), and several are in fact considered as dangerous (B1; European Commission - Pesticides Database, 2015) or at least harmful for bees (B2; European Commission Pesticides Database, 2015). The exposure to sublethal doses of neonicotinoids can impair the locomotive and cognitive abilities of bees (Blacquière et al., 2012; Gill et al., 2012; Henry et al., 2012), however, such subtle effects have also been shown for bees exposed to sublethal doses of some alternative substances (European Food Safety Authority, 2012). However, as sublethal effects are currently not considered for bee-risk classifications (Cabrera et al., 2015), these potential impacts are largely unknown for most of the alternative substances and the risks these pose to bees under agronomically realistic conditions may remain undetected. For instance, although the neonicotinoids acetamiprid and thiacloprid can cause sublethal impairments (Blacquière et al., 2012; Godfray et al., 2014, 2015; Brandt et al., 2016), with possible negative consequences for fitness under agronomically realistic conditions, they are still classified as not being dangerous for bees (B4) and can potentially be applied in flowering crops when bees are actively foraging (European Commission - Pesticides Database, 2015). Recent evaluations indicate that our knowledge about both possible risks and benefits of insecticide alternatives to restricted neonicotinoids remains incomplete (European Food Safety Authority, 2012). In addition, information on effects of insecticides is mostly available for honey bees, while there is a lack of knowledge of effects on wild bees and other important insect pollinators, particularly regarding long-term population consequences (European Food Safety Authority, 2012; Godfray et al., 2014, 2015).

In 2009 the European Parliament and Council developed a directive that farming within the European Union should follow the integrated pest management principles (IPM) and contribute to sustainable use of pesticides (European Commission, 2009). The principles of IPM include the use of crop rotation and measures to promote pest natural enemies to control pests, as well as pest level monitoring and a threshold based use of insecticides (European Commission, 2009). This is expected to maintain the long-term efficacy of the insecticides, by reducing the development of resistance in pest populations (European Commission, 2009). However, since IPM depends on the use of insecticides as one of the pest control options (European Commission, 2009), it could therefore produce some of the same problems for beneficial insects that occur when implementing conventional pest management strategies, albeit at a smaller scale.

Besides IPM, the European strategy also considers plant breeding for pest resistance as an opportunity for pest control (Hartung and Schiemann, 2014). The cultivation of crop plants generated by genetic modification (GM) technologies could be an alternative to replace neonicotinoids, but the cultivation of GM crops is still constrained by stringent regulations in the European Union (Hartung and Schiemann, 2014). While the cultivation of plants from conventional breeding is less regulated, it is also less efficient in producing pest-resistant varieties then GM breeding technologies (Hartung and Schiemann, 2014), and may therefore not be an alternative to neonicotinoids in the near future. The most likely alternative to neonicotinoids available to farmers therefore is other insecticides.

Residues of many pesticides, including various insecticides, can be found in the hives of honey bees, with neonicotinoids constituting only a small proportion (Chauzat et al., 2011; Pettis et al., 2013). Hence, it is possible that risks with alternative pest management regimes following a restriction of neonicotinoids may continue to endanger bees and other pollinators, possibly replacing one threat with another. Posing such unpredictable consequences for pollination services could potentially impede future food supply.

Firstly, we conclude that our knowledge about the general impact of insecticides on pollinators is still limited (European Food Safety Authority, 2012). That an insecticide is toxic to individual bees or other pollinators is a trivial finding and the critical issue is whether bees in agricultural landscapes are affected in ways that may reduce the long-term persistence of populations (Cabrera et al., 2015) and in particular the pollination services they provide (Chagnon et al., 2015; Stanley et al., 2015). In addition, studies have been predominantly carried out using honey bees, disregarding that other bee species, as well as other pollinators, may differ in their sensitivity to insecticide exposure (European Food Safety Authority, 2012; Arena and Sgolastra, 2014). We argue that an expanded scientific evidence base is needed to assess the risks and benefits also of alternative pest management strategies.

Secondly, we conclude that current assessments of environmental risks with pest control methods have a limited ability to predict consequences for populations of different pollinator species under natural conditions. Our knowledge about direct and indirect effects of pest control on bees, in particular on bee populations under field conditions and 
resulting consequences on pollination services is rudimentary, and our knowledge about effects on other pollinators is virtually non-existent. Reports of sublethal effects on bees leading to impaired locomotive and cognitive abilities (Blacquière et al., 2012; Gill et al., 2012; Henry et al., 2012), decreased reproductive success (Whitehorn et al., 2012; Rundlöf et al., 2015) and the insufficient provision of pollination services to crops (Stanley et al., 2015), call for the use of new approaches to such risk assessments. An alternative assessment would be measuring sublethal effects as endpoints after insecticide exposure, to inform environmental risk assessments and thereby potentially also regulatory decisions (European Food Safety Authority, 2012; Cabrera et al., 2015). Such consequences cannot easily be revealed in laboratory studies alone, because only field studies may reveal if such effects appear under agronomically realistic conditions (Cabrera et al., 2015) where bees have to work to collect their food and if this translates to fitness consequences (Mommaerts et al., 2010). We argue that to allow informed

\section{REFERENCES}

Arena, M., and Sgolastra, F. (2014). A meta-analysis comparing the sensitivity of bees to pesticides. Ecotoxicology 23, 324-334. doi: 10.1007/s10646-014-1190-1

Arthropod Pesticide Resistance Database (2015). Arthropod Pesticide Resistance Database - Insecticide Resistance Action Committee, Michigan State University. Available online at: http://www.pesticideresistance.org/index.php

Blacquière, T., Smagghe, G., van Gestel, C. A. M., and Mommaerts, V. (2012). Neonicotinoids in bees: a review on concentrations, side-effects and risk assessment. Ecotoxicology 21, 973-992. doi: 10.1007/s10646-012-0863-x

Brandt, A., Gorenflo, A., Siede, R., Meixner, M., and Büchler, R. (2016). The neonicotinoids thiacloprid, imidacloprid, and clothianidin affect the immunocompetence of honey bees (Apis mellifera L.). J. Insect Physiol. 86, 40-47. doi: 10.1016/j.jinsphys.2016.01.001

Cabrera, A. R., Almanza, M. T., Cutler, G. C., Fischer, D. L., Hinarejos, S., Lewis, G., et al. (2015). Initial recommendations for higher-tier risk assessment protocols for bumble bees, Bombus spp. (Hymenoptera: Apidae). Integr. Environ. Assess. Manag. doi: 10.1002/ieam.1675. [Epub ahead of print].

Chagnon, M., Kreutzweiser, D., Mitchell, E. A., Morrissey, C. A., Noome, D. A., and Van der Sluijs, J. P. (2015). Risks of large-scale use of systemic insecticides to ecosystem functioning and services. Environ. Sci. Pollut. Res. 22, 119-134. doi: 10.1007/s11356-014-3277-x

Chauzat, M. P., Martel, A. C., Cougoule, N., Porta, P., Lachaize, J., Zeggane, S., et al. (2011). An assessment of honeybee colony matrices, Apis mellifera (Hymenoptera: Apidae) to monitor pesticide presence in continental France. Environ. Toxicol. Chem. 30, 103-111. doi: 10.1002/etc.361

Elbert, A., Haas, M., Springer, B., Thielert, W., and Nauen, R. (2008). Applied aspects of neonicotinoid uses in crop protection. Pest Manag. Sci. 64, 1099-1105. doi: 10.1002/ps.1616

Essential Chemical Industry online (2015). Essential Chemical Industry online Department of Chemistry, University of York. Available online at: http://www. essentialchemicalindustry.org/index.php

European Commission (2013). European Commission, Commission Implementing Regulation (EU) No 485/2013 of 24 May 2013 Amending Implementing Regulation (EU) No 540/2011, as Regards the Conditions of Approval of the Active Substances Clothianidin, Thiamethoxam and Imidacloprid, and Prohibiting the Use and Sale of Seeds Treated with Plant Protection Products Containing those Active Substances.(Official Journal of the European Union, Vol. 139, 12-26. Available online at: http://eur-lex.europa.eu/legal-content/ EN/ALL/?uri=CELEX:32013R0485

European Commission (2009). European Commission, Directive 2009/128/EC of the European Parliament and of the Council of 21 October 2009 Establishing a Framework for Community Action to Achieve the Sustainable Use of Pesticides. Official Journal of the European Union Vol. 309, 71-86. Available online at: http://eur-lex.europa.eu/legal-content/EN/ALL/?uri=CELEX:32009L0128 decisions a combination of laboratory, semi-field, and field studies is necessary (Cabrera et al., 2015), considering for example multiple routes of exposure as well as including both lethal and sublethal effects on both wild and managed bee species (European Food Safety Authority, 2012).

\section{AUTHOR CONTRIBUTIONS}

BKK conceived and led the project. All authors listed, have made substantial, direct and intellectual contribution to the work, and approved it for publication.

\section{FUNDING}

This work was funded by FORMAS through the strong research environment SAPES and strategic research environment BECC. MR was funded by the Swedish Research Council (330-20146439).

European Commission - Pesticides Database (2015). Available online at: http://ec. europa.eu/sanco_pesticides/public/?event=homepage\&language $=\mathrm{EN}$

European Food Safety Authority (2012). European Food Safety Authority, Scientific Opinion on the science behind the development of a risk assessment of Plant Protection Products on bees (Apis mellifera, Bombus spp. and solitary bees). EFSA J. 10:2668. doi: 10.2903/j.efsa.2012.2668

Garibaldi, L. A., Steffan-Dewenter, I., Winfree, R., Aizen, M. A., Bommarco, R., Cunningham, S. A., et al. (2013). Wild pollinators enhance fruit set of crops regardless of honey bee abundance. Science 339, 1608-1611. doi: $10.1126 /$ science. 1230200

Gill, R. J., Ramos-Rodriguez, O., and Raine, N. E. (2012). Combined pesticide exposure severely affects individual- and colony -level traits in bees. Nature 491, 105-108. doi: 10.1038/nature11585

Godfray, H. J. C., Beddington, J. R., Crute, I. R., Haddad, L., Lawrence, D., Muir, J. F., et al. (2010). Food security: the challenge of feeding 9 billion people. Science 333, 812-818. doi: 10.1126/science.1185383

Godfray, H. C. J., Blacquière, T., Field, L. M., Hails, R. S., Petrokofsky, G., Potts, S. G., et al. (2014). A restatement of the natural science evidence base concerning neonicotinoid insecticides and insect pollinators. Proc. R. Soc. B Biol. Sci. 281:20140558. doi: 10.1098/rspb.2014.0558

Godfray, H. C. J., Blacquière, T., Field, L. M., Hails, R. S., Potts, S. G., Raine, N. E., et al. (2015). A restatement of recent advances in the natural science evidence base concerning neonicotinoid insecticides and insect pollinators. Proc. R. Soc. B 282:20151821. doi: 10.1098/rspb.2015.1821

Goulson, D. (2013). Review: an overview of the environmental risks posed by neonicotinoid insecticides. J. Appl. Ecol. 50, 977-987. doi: 10.1111/13652664.12111

Goulson, D., Nicholls, E., Botías, C., and Rotheray, E. L. (2015). Bee declines driven by combined stress from parasites, pesticides, and lack of flowers. Science 347:1255957. doi: 10.1126/science. 1255957

Gray, G. M., and Hammitt, J. K. (2000). Risk/risk trade-offs in pesticide regulation: an exploratory analysis of the public health effects of a ban on organophosphate and carbamate pesticides. Risk Anal. 20, 665-680. doi: $10.1111 / 0272-4332.205060$

Hartung, F., and Schiemann, J. (2014). Precise plant breeding using new genome editing techniques: opportunities, safety and regulation in the EU. Plant J. 78, 742-752. doi: 10.1111/tpj.12413

Heimbach, U., and Müller, A. (2013). Incidence of pyrethroid resistant oilseed rape pests in Germany. Pest Manag. Sci. 69, 209-216. doi: 10.1002/ ps.3351

Henry, M., Beguin, M., Requier, F., Rollin, O., Odoux, J. F., Aupinel, P., et al. (2012). A common pesticide decreases foraging success and survival in honey bees. Science 336, 348-350. doi: 10.1126/science.1215039

Hughes, J., Reay, G., and Watson, J. (2014). "Insecticide use on Scottish oilseed rape crops: historical use patterns and pest control options in the absence of 
neonicotinoid seed treatments," in Proceedings Crop Protection in Northern Britain (Dundee), 21-26.

Klatt, B. K., Holzschuh, A., Westphal, C., Clough, Y., Smit, I., Pawelzik, E., et al. (2014). Bee pollination improves crop quality, shelf life and commercial value. Proc. R. Soc. B 281:20132440. doi: 10.1098/rspb.2013.2440

Klein, A.-M., Vaissiere, B. E., Cane, J. H., Steffan-Dewenter, I., Cunningham, S. A., Kremen, C., et al. (2007). Importance of pollinators in changing landscapes for world crops. Proc. R. Soc. B 274, 303-313. doi: 10.1098/rspb.200 6.3721

Lautenbach, S., Seppelt, R., Liebscher, J., and Dormann, C. F. (2012). Spatial and temporal trends of global pollination benefit. PLOS ONE 7:e35954. doi: 10.1371/journal.pone.0035954

Mommaerts, V., Reynders, S., Boulet, J., Besard, L., Sterk, G., and Smagghe, G. (2010). Risk assessment for side-effects of neonicotinoids against bumblebees with and without impairing foraging behavior. Ecotoxicology 19, 207-215. doi: 10.1007/s10646-009-0406-2

Noleppa, S., and Hahn, T. (2013). The Value of Neonicotinoid Seed Treatment in the European Union. HFFA Working Paper 01/2013, Humbolt forum for Food and Agriculture.

Pettis, J. S., Lichtenberg, E. M., Andree, M., Stitzinger, J., Rose, R., and Vanengelsdorp, D. (2013). Crop pollination exposes honey bees to pesticides which alters their susceptibility to the gut pathogen Nosema ceranae. PLoS ONE 8:e70182. doi: 10.1371/journal.pone.0070182

Rundlöf, M., Andersson, G. K., Bommarco, R., Fries, I., Hederström, V., Herbertsson, L., et al. (2015). Seed coating with a neonicotinoid insecticide negatively affects wild bees. Nature 521, 77-80. doi: 10.1038/nature 14420

Sánchez-Bayo, F., Tennekes, H. A., and Goka, K. (2013). "Impact of systemic insecticides on organisms and ecosystems," in Insecticides - Development of
Safer and More Effective Technologies, ed S. Trdan (Vienna: INTECH Open Access Publisher), 365-414

Smith, M. R., Singh, G. M., Mozaffarian, D., and Myers, S. S. (2015). Effects of decreases of animal pollinators on human nutrition and global health: a modelling analysis. Lancet 386, 1964-1972. doi: 10.1016/S0140-6736(15)6 $1085-6$

Stanley, D. A., Garratt, M. P. D., Wickens, J. B., Wickens, V. J., Potts, S. G., and Raine, N. E. (2015). Neonicotinoid pesticide exposure impairs crop pollination services provided by bumblebees. Nature 528, 548-550. doi: 10.1038 /nature 16167

United States Environmental Protection Agency (2014). Benefits of Neonicotinoid Seed Treatments to Soybean Production, United States Environmental Protection Agency Report. Available online at: http://www2.epa.gov/ pollinator-protection/benefits-neonicotinoid-seed-treatments-soybeanproduction

Whitehorn, P. R., O'Connor, S., Wackers, F. L., and Goulson, D. (2012). Neonicotinoid pesticide reduces bumble bee colony growth and queen production. Science 336, 351-352. doi: 10.1126/science.1215025

Conflict of Interest Statement: The authors declare that the research was conducted in the absence of any commercial or financial relationships that could be construed as a potential conflict of interest.

Copyright (c) 2016 Klatt, Rundlöf and Smith. This is an open-access article distributed under the terms of the Creative Commons Attribution License (CC BY). The use, distribution or reproduction in other forums is permitted, provided the original author(s) or licensor are credited and that the original publication in this journal is cited, in accordance with accepted academic practice. No use, distribution or reproduction is permitted which does not comply with these terms. 